\title{
Pengembangan Aplikasi Mobile Guru Tajwid berbasis Android
}

\author{
Andi Azizul Abdul Hakim Al Fajri \\ Jurusan Pendidikan Teknik Elektro, Universitas Negeri Makassar \\ andiazizul1905@gmail.com
}

\begin{abstract}
Abstrak - Penelitian ini merupakan penelitian pengembangan perangkat lunak dengan model pengembangan prototipe. Tujuan penelitian ini adalah pengembangan aplikasi mobile Guru Tajwid berbasis Android, dan untuk mengetahui hasil uji kelayakan aplikasi mobile Tajwid Guru dengan menggunakan standar ISO 25010. Data penelitian diperoleh dari observasi dan kuesioner oleh responden. Hasil pengujian aplikasi diperoleh dengan menganalisis aspek kesesuaian fungsional, kegunaan, kompatibilitas dan portabilitas. Pada aspek kesesuaian fungsional diperoleh persentase $100 \%$ dengan kategori dapat diterima. Pada aspek usability kategori sangat setuju memiliki frekuensi 27 dengan persentase 90\%, kemudian pengguna aplikasi dengan kategori setuju memiliki frekuensi 3 dengan persentase 10\%, sehingga aplikasi dinyatakan memenuhi syarat dan ditanggapi dengan baik oleh pengguna. Pada aspek kompatibilitas, aplikasi Tajwid Guru dapat berjalan dengan baik. Dari segi portabilitas, aplikasi Tajwid Guru dapat berjalan dengan baik.
\end{abstract}

Kata kunci: Aplikasi Seluler, Guru Tajwid, Android

\section{PENDAHULUAN}

Membaca Al Qur'an dengan tartil atau tidak tergesa-gesa dan sesuai ilmu Tajwid adalah suatu kewajiban bagi setiap muslim. Artinya setiap muslim harus mempelajari tata cara membaca $\mathrm{Al}$ Qur'an dengan tartil sesuai dengan ilmu Tajwid. Sebagaimana firman Allah dalam QS. Al- Muzammil/73:4, "Dan bacalah Al Quran itu dengan tartil (perlahan-lahan)". (Departemen Agama, 2002).

KH. As'ad Humam dalam bukuya "Cara Cepat Belajar Tajwid Praktis" (kelanjutan dari 6 jilid buku Iqra) menegaskan bahwa hukum mempelajari ilmu Tajwid (mengetahui istilah-istilah dan hukum-hukumnya) adalah Fardhu Kifayah sedangkan membaca Al Qur'an dengan tartil (membaguskan bacaan huruf-huruf $\mathrm{Al}$ Qur'an dengan terang, teratur dan tidak terburu-buru serta mengenal tempat waqaf sesuai dengan aturan ilmu Tajwid) adalah Fardhu Ain (wajib bagi tiap kaum muslim). Bagi guru/calon guru Al Qur'an, perlu mempelajari semuanya baik teori maupun praktek Tajwidnya, sedangkan bagi santri-santri yang hanya ingin dapat membaca Al Qur'an dengan baik cukup hanya mengetahui latihan dan prakteknya saja, jadi tidak harus menguasai istilah-istilahnya. Namun menguasai kedua- duanya jelas lebih baik. (Humam, 2002). Kemampuan baca Al Qur'an umat Islam saat ini masih memprihatinkan, karena sebagian besar penduduk negeri ini yang notabene adalah beragama Islam, ternyata kemampuan membaca Al Qur'annya sangatlah minim. Hasil riset dari Institut Ilmu Al Qur'an (IIQ) mencatat sekitar 65 persen masyarakat Indonesia buta huruf Al Qur'an. Dewan Dakwah Islamiyah Indonesia (DDII) menilai bahwa permasalahan tersebut harus menjadi perhatian bagi semua kalangan. Tentu masalah ini akan berakibat kurangnya interaksi dengan $\mathrm{Al}$ Qur'an dan akhirnya mengakibatkan umat tidak mengamalkan Al Qur'an. (Sadiah, dkk. 2018)

Kemampuan membaca Al Qur'an yang memprihatinkan disebabkan oleh beberapa faktor antara lain metode pengajaran yang kurang tepat, guru yang kurang memadai, media pembelajaran yang kurang mendukung, terbatasnya informasi dan aktivitas yang banyak. Dengan melihat aktivitas yang cukup banyak, orang-orang lebih memilih belajar di tempat kursus, berdiskusi denga teman ataupun belajar secara mandiri.

Pembelajaran melalui aplikasi android adalah salah satu solusi belajar mandiri yang efektif. Pembelajaran tersebut dapat berperan sebagai seorang guru maya. Strategi ini ditempuh dengan tujuan lebih mampu menarik minat pengguna karena tidak mengenal tempat dan waktu, sehingga belajar menggunakan smartphone lebih efektif karena dapat dilakukan di manapun dan kapanpun. Adanya program aplikasi mobile ilmu Tajwid pada smartphone android, tentunya akan memberikan dampak positif bagi masyarakat sehingga deskripsi-deskripsi definisi aturan membaca Al Qur'an dapat dimengerti dengan jelas dan mudah, karena aplikasi mobile yang berbasis android tentunya mudah untuk dibawa ke mana saja dan sangat menarik perhatian di kalangan masyarakat. Dengan adanya pengembangan aplikasi ini diharapkan dapat menjadi solusi dari masalah-masalah tersebut.

Berdasarkan latar belakang masalah maka dibuat rumusan masalah sebagai berikut: Bagaimana hasil pengembangan aplikasi mobile Guru Tajwid pada android? dan Bagaimana hasil uji aplikasi mobile Guru Tajwid menggunakan ISO 25015?

\section{LANDASAN TEORI DAN KERANGKA BERPIKIR}

A. Pengembangan: Pengembangan adalah suatu usaha untuk meningkatkan kemampuan teknis, teoritis, konseptual, dan moral sesuai dengan kebutuhan melalui pendidikan dan latihan. Pengembangan adalah suatu proses mendesain pembelajaran secara logis, dan sistematis dalam rangka untuk menetapkan segala sesuatu yang akan dilaksanakan dalam proses kegiatan belajar dengan memperhatikan potensi dan kompetensi peserta didik. (Majid, 2005)

B. Android Studio: Android Studio merupakan sebuah IDE (Integrated Development Environment) untuk pengembangan aplikasi android, aplikasi ini dipublikasikan oleh Google pada tanggal 16 Mei 2013 dan tersedia secara gratis di bawah lisensi Apache 2.0, Android studio ini menggantikan software pengembangan android sebelumnya yaitu Eclipse. (Maiyana, 2018)

C. Aplikasi: Aplikasi adalah satu unit perangkat lunak yang dibuat untuk melayani kebutuhan akan beberapa aktivitas. Aplikasi terdiri dari suatu kelompok dokumen yang bekerja berdasarkan fungsinya masing-masing dan membentuk suatu fungsi utama yang bertujuan unuk melayani kebutuhan. (Martono, 2010)

D. Android: Android menawarkan sebuah lingkungan yang berbeda untuk pengembang. Setiap aplikasi memiliki tingkatan yang sama. Android tidak membedakan antara aplikasi inti dengan aplikasi pihak ketiga. Application Programming Interface (API) yang disediakan menawarkan akses ke hardware, maupun data-data smartphone sekalipun, atau data sistem sendiri. Bahkan user dapat menghapus aplikasi inti dan menggantikannya dengan aplikasi pihak ketiga. (Nazaruddin, 2011).

E. Tajwid: Ilmu Tajwid adalah pelajaran untuk memperbaiki 
bacaan Al Qur'an. Ilmu Tajwid itu diajarkan sesudah pandai membaca huruf Arab dan telah dapat membaca Al Qur'an sekedarnya. (Alam, 1994: 15)

F. Kerangka Pikir: Adanya program aplikasi mobile ilmu Tajwid pada smartphone android, tentunya akan memberikan dampak positif bagi masyarakat sehingga deskripsi-deskripsi definisi aturan membaca $\mathrm{Al}$ Qur'an dapat dimengerti dengan jelas dan mudah, karena aplikasi mobile yang berbasis android tentunya mudah untuk dibawa ke mana saja dan sangat menarik perhatian di kalangan masyarakat. Kerangka pikir dalam penelitian ini dapat dilihat pada Gambar dibawah ini:

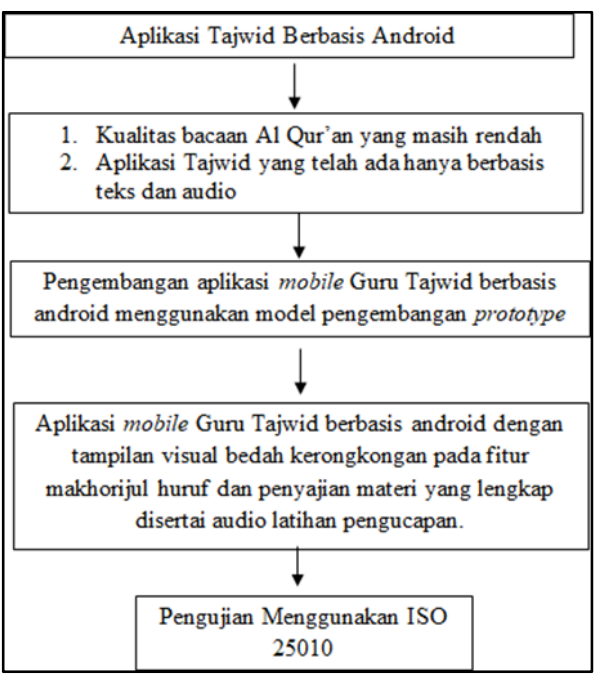

Gambar 1. Kerangka Pikir Pengembangan Aplikasi Guru Tajwid

\section{III.METODE PENEITIAN}

Jenis penelitian yang digunakan adalah jenis penelitian pengembangan perangkat lunak (software development) yang bertujuan untuk mengembangkan aplikasi mobile Guru Tajwid berbasis android dan menguji kelayakan perangkat lunak.

Pada penelitian ini menggunakan model pengembangan perangkat lunak menggunakan model prototype. Prototype merupakan salah satu model pengembangan perangkat lunak yang banyak digunakan, di mana developer dan client dapat saling membantu satu sama lain dalam merancang suatu sistem. Tidak hanya ikut turut serta pada tahap awal saja, namun akan berlanjut terus hingga pada tahap terakhir dan sistem dapat berjalan dengan baik sesuai dengan perencanaan. Proses-proses tersebut dapat dilihat pada Gambar berikut:

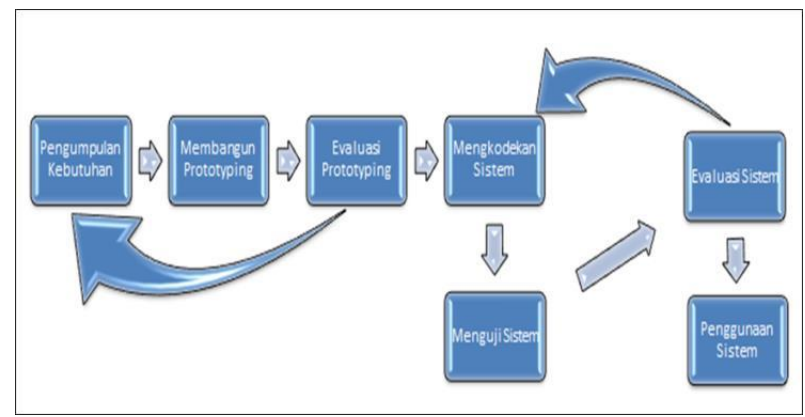

Gambar 2. Tahapan-Tahapan Prototype (Sumber: Hanif, 2007)

\section{IV.HASIL DAN PEMBAHASAN}

A. Hasil Penelitian

Pada bagian ini akan diuraikan hasil penelitian yang telah dilakukan, yaitu berupa hasil pengembangan aplikasi mobile Guru Tajwid berbasis android dan hasil pengujian aplikasi menggunakan standar ISO 25010.

1. Hasil Analisis Kebutuhan: Analisis kebutuhan dilakukan dengan cara observasi. Observasi dilakukan untuk mengetahui aplikasi tajwid yang telah ada dan menganalisis kekurangan pada aplikasi yang telah ada tersebut. Observasi yang dilakukan melalui aplikasi Play Store pada smartphone android. Hasil Observasi dan analisis terhadap kekurangan beberapa aplikasi yang berhubungan dengan pembelajaran hukum tajwid diperoleh kesimpulan sebagai berikut:

a. Aplikasi tajwid yang ada saat ini belum memiliki tampilan visual, hanya sebatas teks dan audio.

b. Aplikasi tajwid yang ada saat ini masih sebatas penyebutan huruf hijaiyyah dan hukum nun sukun/tanwin

2. Hasil Membangun Prototyping: Berdasarkan hasil analisis kebutuhan, langkah selanjutnya adalah membangun prototyping. Tahapan ini dilakukan dengan membuat rancangan sementara yang berfokus dengan penyajian pada user. Rancangan ini terdiri atas rancangan use case diagram, diagram activity, data flow diagram, flowchart dan storyboard.

3. Hasil Evaluasi Prototyping: Evaluasi ini dilakukan oleh pengguna, apakah prototype yang sudah dibangun sesuai dengan keinginan pengguna atau belum. Jika sudah sesuai, maka langkah selanjutnya akan diambil. Namun jika tidak, prototype akan direvisi. Dalam penelitian ini juga dilakukan evaluasi oleh ahli media dan juga ahli konten. Hasil dari evaluasi prototyping oleh ahli yaitu developer diminta menambahkan tombol back, next dan home serta menambahkan pembagian materi qalqalah menjadi dua bagian.

4. Hasil Mengkodekan Sistem: Pada tahap ini prototyping yang sudah disepakati diterjemahkan ke dalam bahasa pemograman yang sesuai. Aplikasi yang digunakan untuk melakukan pengkodean sistem adalah Android Studio 3.5.3 versi 64 bit. Hasil pengkodean aplikasi ditunjukkan pada bagian berikut:

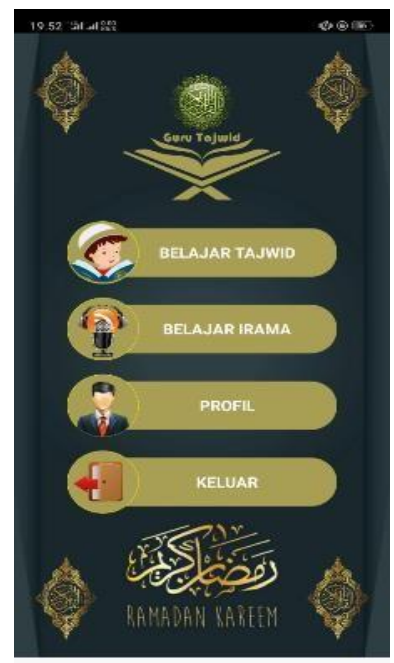

Gambar 3. Tampilan Menu Utama

B. Pembahasan

Aplikasi Guru Tajwid ini merupakan aplikasi yang dikembangkan untuk membantu masyarakat dalam meningkatkan kualitas bacaan Al Qur'an khususnya bagi masyarakat yang terkendala masalah waktu belajar atau kurangnya informasi seputar pembelajaran Al Qur'an. Manfaat adanya aplikasi Guru 
Tajwid ini dapat mengedukasi kaidah-kaidah hukum bacaan dalam Al Qur'an dan irama-irama saat membaca Al Qur'an kepada masyarakat umum.

Aplikasi Guru Tajwid merupakan aplikasi pembelajaran ilmu tajwid berbasis android yang memuat berbagai materi seputar hukum tajwid mulai dari penyebutan huruf hijaiyyah sampai materi hukum mad yang membantu pengguna dalam meningkatkan kualitas bacaan Al Qur'annya. Aplikasi ini dilengkapi dengan tampilan visual bedah kerongkongan pada materi penyebutan huruf hijaiyyah dan audio pembacaan contoh ayat pada setiap materi, adanya tampilan visual dan audio ini dapat membantu pengguna untuk lebih mudah memahami materi yang disajikan pada aplikasi. Hal ini diperkuat oleh kajian teori pada BAB II.

Aplikasi Guru tajwid juga merupakan aplikasi pembelajaran irama dalam membaca Al Qur'an, sehingga bagi para pengguna yang telah mampu membaca Al Qur'an dengan fasih bisa meningkatkan kualitas bacaannya dengan belajar irama sehingga bacaan Al Qur'an yang dilantunkan bisa membuat pembacanya khusyu' dan lebih menyentuh hati bagi para pendengarnya. Hal ini diperkuat oleh kajian teori pada BAB II.

Kelebihan aplikasi Guru Tajwid ini dari aplikasi yang telah ada yaitu aplikasi ini memiliki tampilan visual bedah kerongkongan pada menu penyebutan huruf hijaiyyah, aplikasi ini juga dilengkapi dengan fitur belajar irama dalam membaca $\mathrm{Al}$ Qur'an bagi masyarakat yang telah mampu membaca Al Qur'an secara baik dan ingin memperindah bacaan Al Qur'annya serta aplikasi ini dapat diakses secara offline. Adapun kelemahan dari aplikasi Guru Tajwid ini yaitu penjelasan materi yang singkat dan beberapa materi hanya dilengkapi dengan 1 contoh bacaan ayat, suara yang dihasilkan pada saat memutar contoh bacaan ayat masih kurang jernih dan juga kapasitas aplikasi yang cukup besar. Pengembangan aplikasi Guru Tajwid menggunakan jenis penelitian pengembangan perangkat lunak (software development) dengan model pengembangan prototype. Aplikasi ini diuji dengan menggunakan standar ISO 25010 yang terdiri dari aspek functional suitability, usability, compability dan portability.

Pengujian aspek functional suitability dilakukan dengan menguji fungsionalitas aplikasi oleh validator ahli. Berdasarkan hasil pengujian diperoleh persentase $100 \%$, sehingga dapat disimpulkan bahwa aplikasi Guru Tajwid memenuhi aspek functional suitability dan memiliki kualitas yang layak. Pengujian aspek usability dilakukan dengan membagikan angket kepada pengguna. Hasil dari pengujian aspek usability menunjukkan bahwa aplikasi Guru Tajwid mendapatkan tanggapan baik dari responden.

Hasil dari pengujian aspek compatibility dengan 4 aplikasi yang berbeda yang diakses secara bersamaan, aplikasi Guru Tajwid dapat berjalan dengan baik sehingga dapat disimpulkan bahwa aplikasi Guru Tajwid memenuhi aspek compatibility. Pengujian aspek portability dilakukan dengan menjalankan aplikasi Guru Tajwid pada berbagai macam sistem operasi android. Hasil dari pengujian aspek portability dengan menggunakan 3 jenis smartphone yang berbeda, aplikasi Guru Tajwid dapat berjalan dengan baik sehingga dapat disimpulkan bahwa aplikasi Guru Tajwid memenuhi aspek portability.

\section{KESIMPULAN DAN SARAN}

A. Kesimpulan

Berdasarkan analisis hasil penelitian dan pembahasan pada bab sebelumnya, dapat disimpulkan bahwa:

1. Hasil pengembangan dalam penelitian ini berupa aplikasi mobile pembelajaran hukum tajwid untuk meningkatkan kualitas bacaan Al Qur'an di masyarakat. Pada pengembangan aplikasi ini menggunakan model pengembangan prototyping. Aplikasi ini dikembangkan menggunakan software Android Studio dengan bahasa pemograman XML dan Java di dalamnya. Aplikasi Guru Tajwid memiliki fitur utama yaitu: a) Belajar Tajwid dan b) Belajar Irama.

2. Hasil kelayakan kualitas aplikasi Guru Tajwid diuji menggunakan standar ISO 25010. Pada aspek functional suitability diperoleh persentase $100 \%$ dengan kategori layak diterima. Pada aspek usability dari ujicoba pengguna aplikasi dengan kategori sangat setuju memiliki frekuensi 27 dengan persentase $90 \%$, lalu pengguna aplikasi dengan kategori setuju memiliki frekuensi 3 dengan persentase $10 \%$. Berdasarkan skor tersebut aplikasi dinyatakan layak dan ditanggapi baik oleh pengguna. Pada aspek compatibility, aplikasi Guru Tajwid dapat berjalan dengan baik. Pada aspek portability, aplikasi Guru Tajwid dapat berjalan dengan baik.

B. Saran

Berdasarkan hasil penelitian yang menyatakan bahwa produk sangat baik, namun dalam rangka upaya penyempurnaan produk maka sangat dibutuhkan beberapa saran antara lain:

1. Peruntukan aplikasi ini hanya sebatas smartphone android sehingga pada pengembangan berikutnya dapat membuat aplikasi ini berjalan pada sistem operasi Windows dan IOS.

2. Bagi siswa Pembahasan materi lebih detail.

3. Kelemahan aplikasi ada pada audio contoh bacaan ayat yang kurang jernih jadi kiranya kualitas audio bisa lebih jernih.

\section{DAFTAR PUSTAKA}

[1] Departemen Agama. 2002. Mushaf Al-Quran Terjemah. Depok.

[2] Humam, As'ad. 2002. Cara Cepat Belajar Tajwid Praktis. Yogyakarta: Balai Litbang LPTQ Nasional, Team Tadarus AMM

[3] Maiyana, E. (2018). Pemanfaatan Android dalam Perancangan Aplikasi Kumpulan Doa. Jurnal Sains Dan Informatika, 4(1), 54-65. https://doi.org/10.22216/jsi.v4i1.3409

[4] Majid, Abdul. 2005. Perencanaan Pembelajaran. Bandung: Remaja Rosdakarya.

[5] Martono, Nanang. 2010. Metode Penelitian Kuantitatif. Jakarta: PT Raya Grafindo Persada.

[6] Sadiah, Rahendra Maya, dan Unang Wahidin. 2018. Implementasi Model Pembelajaran dalam Memberantas Buta Huruf Al-Qur'an di Majelis Taklim Nurul Hikmah Kampung Situ Uncal Desa Purwasari Kecamatan Dramaga Kabupaten Bogor. Prosa PAI: Prosiding Al Hidayah Pendidikan Agama Islam, 1(01). hlm. 3. 